This is a pre-copyedited, author-produced version of an article accepted for publication in Journal of Design History following peer review. The version of record Lara-Betancourt, Patricia and Rezende, Livia (2019) Locating design exchanges in Latin America and the Caribbean. Journal of Design History, 32(1), pp. 1-16. is available online at:https://academic.oup.com/jdh/article/32/1/1/5298279 . 


\title{
Locating Design Exchanges in Latin America and the Caribbean
}

Article category: Introduction for the Special Issue 'Locating Design Exchanges in Latin America and the Caribbean'

Word count: 8,773 (with endnotes) / 6,197 (without)

\begin{abstract}
What happens when research and researchers discern and foreground Latin American and Caribbean agency in design? Guided by this challenge, we sought to create over three years of collaborative project a new approach to the research and discourse on Latin American and Caribbean design history. Through the formation of a network of scholars working across the globe, the organization of dedicated themed panels in international conferences, and the culmination of these efforts in the present edited volume, we propose to decolonize and globalize the study of design history in and from that region. To this end, this Introduction situates the fluctuation of interest in Latin American and Caribbean Studies in Europe and the United States, and discusses how the development of Latin American and Caribbean design history need not follow some of the colonialist premises instigated by area studies' scholars. Rather, through a critical review of historiographical trends found in both area studies and in design studies and history journal articles, this Introduction offers an interpretation of how and why design historical understanding has been produced in and from that region, and points to fruitful developments in this scholarship. In order to highlight design agency, we propose to focus on 'design exchanges', understood as meetings and encounters of cultural practices, peoples and objects.
\end{abstract}

Keywords: global design history; decolonization; Latin America; Caribbean; exchanges; agency

\section{A global and decolonial endeavour}

In Kharô indigenous knowledge, the white people have been the advent of Kharô's own bad choices. 'Aukê, rejected by his community for his powers of transformation, tried several times to please the community, to no avail. He wanted his people to possess the firearm, the plate, and all the material culture universe that nowadays is in the hands of the white people. Aukê's grandfather, however, rejected the offer, choosing instead the arc and the gourd. Thus, the white people gained the possibility to create cities and possess technology and, this way, subjugate the indigenous people.'1 
A study into Latin America's and the Caribbean's past through material culture and design need not begin with white people shooting firearms, creating cities, and spreading Western modernity. The territory has comprised experiences, temporalities and spatialities other than those enforced by colonialists and their descendants since the sixteenth century. ${ }^{2}$ Latin America's past is much longer and complex than its history. Kharôs, Incas, Moches or Mayas are among several hundred different peoples and cultures that preceded the European colonial project, developed sophisticated scientific knowledge and technological apparatuses, and whom to this date partake in the intellectual and cultural make-up of the region. It is thanks to the plurality of languages, cultures and lived experiences of these peoples, together with the influx of Spanish, Portuguese, Africans, British, Japanese, Chinese, Lebanese, among other migrants, that the region resists easy definitions. What then is 'Latin America' and 'the Caribbean' and why can they be useful constructs for the study of design and material culture?

Territorially speaking, and following the parameters of traditional colonialist history, Latin America (and part of the Latin-speaking Caribbean region) has been defined since the nineteenth century as the land mass located below the United States, surrounded by the Atlantic and the Pacific oceans. ' 'Latinidad', to Argentinian literary theorist and decolonial thinker Walter Mignolo, is 'a concept initially associated with the imperial epistemology [...] resignified in France during the first decades of the nineteenth century so as to create a transcontinental sense of community among the "linguistic heirs" of the Western Roman Empire. ${ }^{4}$ Local intellectuals 'echoed the French idea and coined in Spanish the term América Latina in order to link the newly independent South American republics to the tradition of Modernity evolved in concert with the epistemology of Latin'. ${ }^{5}$ However, to employ 'Latin' as a common denominator to homogenize this vast territory and its inhabitants was and still is $-\mathrm{a}$ form of subjugation. ${ }^{6}$ Beyond the hundreds of languages spoken by indigenous peoples, one only has to consider the English- and Dutch-speaking Caribbean to be faced with the region's diversity and cultural wealth. Yet, it is to those two adjectives 'Latin American' and 'Caribbean' - that we turn to name this Special Issue of the Journal of Design History, a decision less intended in ascribing definitions and homogeneity than in welcoming pluralism and criticism of these terms.

To this end, our research and editorial projects foreground 'exchanges' as the guiding principle for a study into the material culture and design in and from the region. This Special Issue seeks to unearth these exchanges employing a global historical framework, locating connections and comparisons - the 'signal methods of global history'7 -, among Latin American and Caribbean nations, and between the region and other geographies. ${ }^{8}$ 'Exchange' refers to meetings and encounters of cultural practices, peoples and objects. It is 
a reciprocal process that implies transfer, transmission, importation, appropriation, adoption, adaptation, circulation and dissemination but one that can go further than that. This approach permits a more comprehensive picture of how culture and design are created, recreated and transformed in a continuous process of giving and taking that affects all parties.

The challenges posed by this Special Issue when calling for contributions were twofold. Firstly, the emphasis on 'global exchanges' were intended to address a lacuna in the historiography of Latin American and Caribbean design history shaped mostly by a recurrent focus on national design histories, a trend to be further discussed below. The second challenge was to countervail the persistent colonialist thinking embedded in a historiography that tends to privilege discourses informed by modernization theory, a method of framing Latin American and Caribbean experiences and the production of its material culture as onedirectional influences received from so-called centres of production and understood as second-rate versions of an European or United States' ideal. ${ }^{9}$ The ultimate raison d'être of this Special Issue is therefore to gauge what happens when research and researchers discern and foreground Latin American and Caribbean agency in design. ${ }^{10}$

\section{Why Latin America and the Caribbean, and why now?}

This Special Issue stems from our own research interests and outputs in this field, and from an on-going collaboration to promote the field of Latin America's design history. For over four years we have been actively involved in developing a network of researchers working towards the development of design history studies in and about Latin America and the Caribbean. In 2014, to challenge the idea of Latin America as autonomous region defined in industrial development terms and framed under a centre-periphery model, we called scholars to form a panel at the $51^{\text {st }}$ Society for Latin American Studies Conference, to be held at the University of Aberdeen the following year. A robust response to the open call for papers ensued, mostly from scholars based in Latin America, demonstrating a significant potential in the field and an unmet demand for a debate of this kind. ${ }^{11}$ In 2015, the network met in Scotland where we held the double panel 'Making Autonomy: Design, Material and Visual culture in Latin America'. This initiative continued at the Design History Society's Annual Conference held in San Francisco, US, later in 2015. The panel 'The Utopia of Autonomy: disseminating modern design in Latin America 1950-1970' sought to explore mid-twentieth century design discourses on design and regional development from a transnational perspective. During this conference, the necessity and timeliness of a publication on Latin American and Caribbean design history was confirmed, and another open call for contributions attracted a wealth of diverse themes and approaches to face the challenges of agency and exchange. ${ }^{12}$ The formation of a network of scholars working on Latin American and Caribbean themes and located across the globe has supported the expansion of this 
field of study, beyond the ideas disseminated in this issue, as they have gone on to contribute to other conferences, publications and research meetings promoted by the network. ${ }^{13}$

Beyond design history, this research and editorial project also critically responds to the broader context of Latin American and Caribbean Studies, an interdisciplinary scholarly field that gained momentum in the United States (U.S.) and Europe during the Cold War, prompted also by the decolonization of Africa and Asia in the 1950s and 1960s. ${ }^{14}$ In a recent appraisal of the reasons why Latin American Studies in university departments and research centres proliferated in this period, the journal Latin American Perspectives proposes that the 'academic interest in Latin America during the early twentieth century was largely shaped by diplomatic history and US expansionism and imperialism' that stems back to the US imposed Monroe Doctrine over the continent since 1823, and the nineteenth-century acquisition of territory through wars with Mexico and Spain. ${ }^{15}$ The 1959 Cuban Revolution destabilized US control over the region, and prompted the rise of popular revolutionary movements throughout Latin America, which were met with further US interventionist measures. ${ }^{16}$ The overthrowing of the left-wing governments of João Goulart (Brazil) in 1964 and Salvador Allende (Chile) in 1973 by repressive military coups aided by the US' Central Intelligence Agency (CIA) forced into exile hundreds of local intellectuals 'who carried with them cultural and political influences that accompanied the establishment of centers of Latin American studies. ${ }^{17}$

In the United Kingdom, the 'Parry Report' written in 1965 by the University Grants Committee provided similar impetus for the establishment of institutes and research centres. ${ }^{18}$ Specialist centres of Latin American Studies were set up in Oxford, London, Cambridge, Glasgow and Liverpool $^{19}$ 'drawing largely on theoretical and methodological approaches in the social sciences, humanities and arts'. ${ }^{20}$ By the late 1990s, nations like Chile, Argentina, Peru, Mexico and Brazil attracted a greater number of researchers ${ }^{21}$, while the Latin American population in the United Kingdom (UK) has been increased significantly since the 1970s. Today, an estimated one million people of Latin American ancestry live in the UK, predominantly Brazilians, Colombians, Ecuadorians and Peruvians, constituting one of the fastest-growing immigrant communities. ${ }^{22}$ The migration is much bigger to the United States, where Hispanics population account for over 52 million. ${ }^{23}$

While Latin American exiles in Europe 'focused on problems of dependency and underdevelopment' ${ }^{24}$, Mignolo retraces how the establishment of Latin American studies in the US corroborated to further that nation's colonial grip: 'after World War II, Latin America would end up being incorporated in the United States Academia and Government as the 
label for one of the branches of Area Studies, and the adjective would become a racial and racist noun that not only identifies the individuals of "Iberian-American" descent but also links us to a set of stereotyped elements that usually homogenize, eroticize and/or discriminate. ${ }^{25}$

Gathering knowledge on non-Western areas of the world would prove crucial to US and European national and international security. Two of the main donors for training, money, resources, scholarships and university posts in and about Latin America were the Ford and the Rockefeller foundations. ${ }^{26}$ This funding significantly impacted the type of research and themes considered worthwhile. Mignolo refers to an understanding of Latin American and the Caribbean that is laden with social class and racial bias, and replicates the entrenched class divisions existent in the continent. Cultural, economic and political local elites in their formal accounts of the region's history tend to dismiss popular cultural manifestations, including design and material culture. The idea of Latin America and the Caribbean as a cohesive region results from a homogenizing process driven by a desire (of victors) to dismiss power struggles and inequality.

After the fall of the Berlin wall and the end of the Cold War, Latin America lost part of its strategic importance when Area Studies were affected by funding cuts and a loss of interest in the region. 'Development' and 'Modernization' as main theoretical frameworks have gradually been replaced by global studies and by an interest in international (rather than national) research projects. After 2005, a renewed interest in Latin American and Caribbean studies emerged from a comparative perspective due to an increasing interest in studying trans-local, transregional, transnational and transcontinental phenomena. ${ }^{27}$ However, none of the disciplines traditionally taught at Latin American and Caribbean research centres or institutes have included design history, even though much of the knowledge produced is relevant to design history, as will be discussed below.

Before we embark on a critical appreciation of the design history scholarship, a word of caution. The adoption of a global historical methodology underpinned by the lenses of exchanges does not confer an immediate restoration of symmetry in history making. Global historians Richard Drayton and David Motadel, citing Latin Americanist Jeremy Adelman, propose that 'the high hopes for cosmopolitan narratives about "encounters" between Westerners and Resterners led to some pretty one-way exchanges about the shape of the global'. ${ }^{28}$ One reason for the imbalance, they say, lies with language skills: 'in general, [global history] is dominated by Anglophone historians who seem unable or indisposed to read history written in other languages. ${ }^{29}$ Likewise, Latin American scholars and writers have been hindered by language barriers and the prevalence of editorial protocols imposed globally by the Anglophone world. ${ }^{30}$ This is where English-speaking Caribbean scholars differ 
from those in Latina America, as exemplified by the work of cultural theorist Stuart Hall and its centrality to the Latin American and Caribbean postcolonial discourses. ${ }^{31}$ Other barriers like travel costs, research grants, etc. have also been an issue for the global expansion of design history in Latin America. Yet, the potential for the development of a global vision and sensibility for global design history in Latin America and the Caribbean is promising. It would help emancipate a lingering colonial attitude towards one's own culture and international positioning if, in Arturo Escobar's proposition, 'radical interdependence' is realized as a global phenomenon rather than a local one. ${ }^{32}$ In a globalized context, the movement of goods, people and the ideas they bear form an ideal site for the study of cultural, economic and political exchanges and encounters. ${ }^{33}$

If in this Special Issue we propose a focus on global exchanges as an alternative to colonialist thinking this approach has not characterised the design literature about the region. At times an uncritical employment of terms like copy, imitation, adoption, among others, omit local agency and dismiss complex global interdependent relations. To assess the design literature about Latin American and Caribbean, we have searched academic journals dedicated to design history and design studies for articles that contribute to an understanding of design, visual and material culture in or from the region. ${ }^{34}$ Also, we searched Anglophone journals pertaining to Latin American and Caribbean Studies for contributions that foreground design, material or visual culture. ${ }^{35}$ Working with a representative rather than an exhaustive sample of journals, two major themes emerged from our qualitative analysis. Firstly, the study of design history as one of modernization, and secondly, the study of modern design, its professionalization and education.

\section{Modernity, Modernization and Modernism: historiographical challenges}

As Javier Gimeno-Martínez remarks for the discipline in general, 'national histories of design have been a common format to reflect on design history. ${ }^{36}$ Confirming his statement, from a preliminary analysis of most articles in our sample for the period 1990 to 2018 , we identified that until around 2010 there has been a significant national approach to studies in the region. In many instances this approach has required a nationalist methodology that in the case of Latin America is linked to modernization themes and theories. ${ }^{37}$ It is understandable that not only Latin American nations but the European ones also emerging in the nineteenth century would privilege national histories to assert their foundation, legitimacy and new identity. National narratives give coherence to a nation's historical processes and provide nationals with a sense of belonging and identity. Furthermore, this historiographic tendency has been useful and productive in unearthing histories and stories relating to design that would otherwise be overlooked. Its major drawback though is that limiting the research's scope to 
individual countries has hindered having a larger perspective including the wider region and a rich web of interconnections. Taking into account Latin America's diversity, a comprehensive study of the region needs to be more than the sum or juxtaposition of its parts. It is only by bringing together local and larger perspectives that an understanding of the impact of historical forces permeating the whole continent can be properly grasped.

An example of the national approach to research in design history is The Journal of Decorative and Propaganda Arts (JDPA), an editorial project that over eighteen years sought to offer an interpretation for Latin American and Caribbean design, visual and material culture. Founded in 1986 by The Wolfsonian Museum (now published by The WolfsonianFlorida International University) it aimed to promote scholarship on the museum's collection of design and propaganda arts. The Journal, mirroring the museum's collection, focuses on the period 1870 to 1945 and, with the help of a large number of colour and black and white illustrations, aims 'to convey to readers the power of design' and 'to tell the story of social, political and technological changes that have transformed the world'. ${ }^{38}$ Although most of the museum's collection pertains to the United States and Europe, four of the Journal's special themed issues were devoted to Latin American and Caribbean countries: Argentina (1992), Brazil (1995), Cuba (1996) and Mexico (2010). There are twelve to fourteen articles per issue all commissioned by the publishers; and its contributors include academics, art and architectural historians but also museum curators, artists, architects, designers and journalists. As a whole, and even if focusing on 'decorative and propaganda arts', these national issues are a significant contribution to design history literature, and deserve to be better-known for their scope, insights and wide range of themes covered: from individual artists, architects and designers; to art and design movements and case studies on urbanization and modernization. For instance, the most recent issue, on Mexico, reveals the extraordinary dynamism in Mexican Culture in the post-revolutionary period, from 1920 to 1950. Behind the cultural explosion and vindication of the vernacular and the indigenous, the research reveals a quest for a deep sense of Mexicanness (Mexicanidad) by artists, designers, architects, writers and intellectuals but also by the state.

In these issues, and as part of nation-building and modernizing efforts, the theme of dissemination and exchange is crucial. The articles examine, for instance, the impact of migration, including waves of European exiles during and after World Wars I and II, that brought designers, architects, artists and educators to the region, and take into account the many locals who travelled to Europe and the US to train professionally. ${ }^{39}$ Some articles examine the role of print media and particularly graphic design in shaping ideas and taste related to modern design. ${ }^{40}$ The issues address processes of urbanization considering the concentrated development that took place in capital and coastal cities. ${ }^{41}$ Several articles 
discuss, for instance, how the transformation of European cities such as Paris and Barcelona became models for the modernization of Latin American cities, hitherto shaped under colonial parameters. ${ }^{42}$ Case studies include the transformation in urban layout and the emergence of new types of buildings, such as opera houses, hotels, train and metro stations and public gardens. ${ }^{43}$

As an example of national design histories, it is significant that the focus of the JDPA is on the decorative and propaganda arts from 1870 to 1945. Regarding Latin America this is a period when design production acquired a political role to disseminate an ideological message on behalf of national leaders. Governments were eager to accept foreign investment, technology and imports as a way of achieving modernization; and art, architecture and design were co-opted for this purpose. ${ }^{44}$ The JDPA articles illustrate how design was harnessed by national building efforts, political parties and revolutionary movements. To a large extent arts and design in Latin America and the Caribbean in this period developed in response to the ambition to modernize. Thus, it is its propaganda role that makes modern design production Latin American.

A limitation with the national approach to design history relates then to the narratives, theoretical frameworks and methodologies with which scholars have chosen to discuss the Latin American region: mainly as one undergoing a process of modernization in which the constitution of the nation-state and the fight for autonomy have been the driving force. Subordinating the region's production of knowledge on design to the countries' modernizing efforts has resulted in a pervasive understanding of design mostly as a product of modern, industrial societies. Referring to architecture, Felipe Hernández explains that Latin America and the Caribbean should be seen as a region of 'multiple temporalities', or 'modernities' coexisting within nations. He frames the idea of modernity as a 'nation-building' narrative; one that has served and serves political purposes but one that falls short of capturing Latin America's complex reality. In his view, we need to go beyond the modernist legacy. Hernández reminds us that an immense number of spontaneous architectures have not been studied including the architecture and design of countries like Bolivia, Colombia and Guatemala, which are largely unknown internationally. ${ }^{45}$

It is important to understand the difference between Latin America's modernity and that of Europe or the United States. There has been a popular but distorted perception of Latin American and Caribbean modernity as one generated abroad and repeated locally. Central to the interpretation of the region's design history has been the relationship between tradition, modernity, cultural modernism and socio-economic modernization. The anthropologist and cultural critic Néstor García Canclini has forged a well-known 
interpretation of these historical and cultural processes. In his book Culturas Híbridas (Hybrid Cultures) he connects a revised theory of modernity with the transformations that have taken place in Latin America and the Caribbean since the 1980s. ${ }^{46}$ He describes how the region has engaged fully with cultural modernism but at the same time has never quite achieved complete socio-economic modernization, thus showing that one process does not necessarily follow the other. García Canclini proposes that Latin American culture should be seen instead, as the result of indigenous, European and African traditions interacting with modern political, social and media forces. In Latin America and the Caribbean, classist and racial miscegenation have produced hybrid formations permeating all social levels. The homes of many upper and middle-class families contain libraries with books and journals in different languages, indigenous arts and crafts, colonial and foreign antiquities, and all the latest in digital technology living easily side by side with traditional social, family and religious practices. Industrialization and modernization processes, even if incomplete and disrupted, have not replaced tradition but have generated deeply complex cultural forms and phenomena. ${ }^{47}$

The problem with the categories and concepts that historians have used to apprehend historical processes is that they have been defined mostly by the European experience and thus fail to apprehend the Latin American and Caribbean reality. In this JDH special issue we propose different perspectives from those that have deemed the region as subaltern to Western ideals and, as said above, focus on global exchanges as an alternative to colonialist thinking. We favour concepts and notions such as 'hybridization' and 'exchanges', and welcome those proposed by our contributors to this issue, such as 'cosmopolitan Cubanidad' (Erica Morawski) and 'creative appropriation' (Adriana Massidda) to enrich the reading of design history processes and the interpretation and assessment of its historiography.

\section{A historiography predicated on modern design canons}

The history of the professionalization of modern design and the institutionalization of its education represents the second significant historiographical trend found in our analysis. Within this trend, certain areas of design practice, namely graphic and product design (also known locally as 'industrial design'), have gained prominence and validity in the design literature. Other design and material practices like craft, for example, were relegated by tastemakers and design authors as non-designed artefacts.

In a recent essay that surveys graphic design historiography in that country, Brazilian scholar Priscila Farias asks rhetorically: 'When does the history of design in Brazil begin?'48 This question, picked up by Farias for the frequency with which it is uttered within this scholarship, 
is usually accompanied by another: 'When does design in Brazil begin?' This line of enquiry, however, is spurious if one subscribes, as we do, to the idea that 'design as a practice and product exists wherever there is human activity. ${ }^{49}$ Design, understood here multifariously as a method of making and of knowledge production, as an organized profession, an institutionalized mode of education, a discourse and an academic discipline, is a term constantly redefined as practices evolve (say, from analogue to digital making) and as historical evidence surface and are interpreted differently (say, as thinking is decolonized). Moreover, intellectual projects interested in finding 'origins' and establishing definitive parameters for historical explanations could be likened to an un-designerly way of knowing. ${ }^{50}$ Contention over origins means contention over narrative, and the owning of historical narratives is a form of power.

Farias' posing of that question has validity, though; in resorting to it, she introduces contentious positions held within traditional echelons of Brazilian and Latin American scholarship to whom establishing an origin for design practice and its institution as an academic-worthy discipline meant to proclaim that design and designers existed in the region. ${ }^{51}$ For some scholars, origins of design practice date back to the arrival of the first printing presses in the continent, for example, or to the post-independence period when the Hispanic Republics sought to reorganize the state apparatus. ${ }^{52}$ Other scholars vehemently locate the beginnings of design practice (and therefore of design history) in the post-World War II period when the educational and professionalized fields of design were more consistently and systematically organized in dedicated schools and professional bodies. ${ }^{53} \mathrm{At}$ each end of this temporal spectrum lies a scholarly reliance on thinking design as a field of practice predicated on the employment of a certain kind of technology and the espousing of a certain modern worldview. It is therefore necessary to differentiate design as 'human activity' - as the Kharô people would do - from the phenomenon of 'modern design', a historicallylocated event of human activity that nonetheless greatly impacted Latin American and Caribbean scholarship.

The mid-twentieth century witnessed the growth of modern design practice and education across the globe. Hundreds of specialized design schools opened and new design pedagogies emerged. Professional associations like the International Council of Societies of Industrial Design (ICSID) founded in 1957 helped organize this nascent profession, promote and regulate its global reach, whereas local associations like the ABDI (Brazilian Association of Industrial Design), founded in 1963, acted locally. ${ }^{54}$ This global growth, however, evolved at different rates and encountered diverse dilemmas in different localities. While in Europe and the United States a booming industry and consumerist society fuelled modern design expansion, in India, for instance, the very condition of economic and social 
underdevelopment ushered in modern design's rationalist and industrialist ethos as tools for progress. ${ }^{55}$

In the post-World War II period, ambitious national plans for infrastructural improvement, industrial development and import substitution were implemented to counter the region's economic and technological dependency on industrialized nations. These national plans included the opening of more than thirty design schools across the region between the $1950 \mathrm{~s}$ and 1980s, and the adoption of a modern graphic design language to communicate progress. ${ }^{56}$ This period marked the emergence of the self-acclaimed modern designers, and the establishment of their professional identity separately to that of architects or interior designers, who always had a firm presence in designing things. ${ }^{57}$

Thus, a history of design predicated on celebrating the establishment of modern design may serve the modernizing project but it elides broader social and historical phenomena. Given its close proximity to political economic histories, this historiography tends to replicate interpretative models commonly found in theories of dependency that framed the region as 'Third World' or peripheral to so-called centres of industrial production. ${ }^{58}$ Hence the perception of Latin American and Caribbean design and material culture as a derivative, a second-rate version of a European or United States' ideal.

Cuban design historian Lucila Fernández Uriarte points to an 'uneasy alliance' and an internal contradiction perpetuated by the design historiography that canonizes modern design. ${ }^{59}$ For Fernández, an 'image' of what design constituted was 'exported to peripheral and non-industrialized countries' whilst the crisis of the modern movement, and the modern world as we know it, erupted in Europe in the end of the 1960s. ${ }^{60}$ In her critique of this 'image', Fernández singles out the work and writings of Gui Bonsiepe, a Hochschule für Gestaltung (HfG) Ulm graduate who moved to Chile in 1968, worked in Argentina in the 1970s, and in Brazil a decade later ${ }^{61}$ Bonsiepe's writings and praxis as educator and designer in South America have been of undeniable importance in the region. In his own words, Bonsiepe characterized his ideas as those of a 'pragmatic rational "ulmian"', whose approach 'made it possible to draw a profile of the industrial designer and to consolidate his education' in the region. ${ }^{62}$ Bonsiepe's call for the industrialization of Latin America proposed that "for the underdeveloped countries of the "Third World", industrial design would become an indispensable factor in overcoming underdevelopment and dependence. ${ }^{63}$ Fernández, however, criticizes Bonsiepe's ideas as contradictory. They propose an acceptation of design as 'strictly characterized by rationality and scientific foundations' but to be employed as the tool for development in a 'social context marked by the backwardness of industry'. ${ }^{64}$ This means, to Fernández, that 'aspirations were not achieved as expected. ${ }^{165}$ As a 
counterstrategy, she calls for the investigation of the 'history of material culture before industrialization', drawing from the work of other historians, including those like Fernando Ortiz and Moreno Fraginal who studied colonial plantations of tobacco and sugar. ${ }^{66}$

This 'uneasy alliance' between underdevelopment and industrialization was also found in the 1980 constitutive act of the Asociación Latinoamericana de Diseño (Latin American Design Association, ALADI), discussed here by Tania Messel. According to Fernández, that document 'defined industrial design as a necessary technological discipline whose most important objective [was] to support the rupture of economic, technological and cultural dependency to which underdeveloped countries find themselves tied. ${ }^{67}$ The seemingly simple logic - to escape underdevelopment countries needed industrialization and industrial design - born contradictions not easily resolved at a local level. Industrial prowess, technological innovation, capital, investment, and skilled labour: where would they come from, and moreover, upon which model would they develop? For Fernández, Latin America and its Third World predicament tied in with an ideology of development through industrialization gave the European 'modernists' an opportunity to reclaim 'the social content of design'. ${ }^{68}$ For Latin Americans, design practice framed as a rational, technical tool promised 'escape from underdevelopment' predicated on a model of modernization and modernity that had unfolded in the demise of modernism in Europe. Fernández astutely asks: 'Paradoxical, wouldn't one say?'69

The scholarly emphasis on histories of design education and the professionalization of practice, interpreted from nation-specific perspectives and celebrating the biographies of successful (usually white, usually male) designers (framed as 'pioneers') results from an initial lack of academic research in the field of design. ${ }^{70}$ According to Farias, 'until the late 1990s, it was very rare to find books about design by Brazilian authors. ${ }^{71}$ The history of Brazilian design (and more specifically of Brazilian graphic and product design) was often regarded as something unimportant or non-existent. ${ }^{72}$ Since the 1990 s, with the creation of the first postgraduate programmes in Design in Brazil and subsequent scholarly infrastructure, scientific conferences and academic journals, 'original research' became possible. ${ }^{73}$ As she points out, only more recently has a 'major shift in thought' promoted by emergent research work, and 'an interest in artefacts produced before or outside the logics of modern design education, and an understanding of graphic design as part of local, visual, print and material culture' started to reject the canons of former heroic, modernist narratives. ${ }^{74}$

\section{In this Issue}


In the intervening years between our first call for papers (2014), the establishment of a new research agenda (2015) and the issuing of this editorial project (2018), much has changed in the political, economic, social and cultural lives of Latin Americans and Caribbeans. Current developments in Venezuela, Brazil and the Windrush scandal in the UK, to name a few, act as sobering reminders that optimistic predictions regarding the region need to be treated cautiously. Yet, the robust response entailed by the call, coupled with the complex debates proposed by contributors in this issue, vouch for the liveliness and urgency in assessing the region and contributing to a more nuanced and critical global account of Latin America and Caribbean's design history.

In the first article, Veronica Devalle discusses the fundamental role that artist, designer and theoretician Tomas Maldonado played in the emergence of design theory in Latin America and the Caribbean and his contribution to developing such theory as director of the Hochschule für Gestaltung (HfG) in Ulm in the 1950s. She argues that Maldonado's work in disseminating the notion of modern design was fundamental to the conceptual foundations of design education in Argentina and globally. The article examines Maldonado as a leading figure in the Argentine avant-garde group Arte Concreto Invención in the 1940s, his fruitful networking relationship with Max Bill and his work as lecturer and director of the HfG. The argument focuses on nueva visión magazine (1951-1957), directed by Maldonado, and the Nueva Visión publishing house, founded in 1954 and directed by Jorge Grisetti, one of Maldonado's disciples.

Also pertaining to Argentina, Adriana Massidda gives a revealing example of design exchanges in urban planning and housing in Buenos Aires. Her article examines the Parque Almirante Brown housing programme (PAB) in the context of international debates about informal settlements. Her analysis shows how the PAB brought together elements from different design and planning traditions, local and international, including those by the Congrès Internationaux d'Architecture Moderne (CIAM). Massidda frames the PAB programme as one of 'creative appropriation', understood as the selective adoption of modernist precepts by local authorities who used modernism 'to portray themselves as the epitome of modernity, effectiveness and order'. This way, Massidda problematizes the notion of 'local' and 'agency' by referring to the political authority whose decisions were made at the expense of slum dwellers' welfare.

Moving to the Caribbean, Erica Morawski analyzes how the local and global can be articulated beyond simplistic one-way influence interpretations. She analyses the design and redesign of the iconic Cuban night club Tropicana by the architect Max Borges in the 1950s based on a range of primary sources: from a preserved and celebrated tropical vegetation to 
the spatial design that enmeshed indoor and outdoor settings; from the material culture of performances to the graphic design of ephemera. Morawski's conceptualization of the 'cosmopolitan Cubanidad', 'a Cuban identity shaped by a cosmopolitan view of itself within the larger world', or simply put, 'a globally situated local identity', is her key contribution to the foregrounding agency and complexifying exchanges in the region. The author proposes this reading as a model and methodology to understand similar buildings and cultures in other Latin American and Caribbean countries.

Changing the focus from interior design to graphic communication, Nicole Cristi \& Javiera Manzi Araneda study in depth two of the most prolific and little-known graphic collectives during the dictatorship in Chile (1973-1989): the Agrupación de Plásticos Jóvenes (APJ) and the Tallersol Cultural Center. They examine the production of political posters as a practice that is political by definition, given the material conditions and social networks supporting it. What is brought to the fore are the technical and relational aspects of these collectives, who were successful in circumventing Pinochet's dictatorial regime's censorship. Cristi and Manzi make a crucial methodological contribution to the archival reconstruction of clandestine or silenced pasts, as they carefully catalogued extant posters, cross-referenced information with in-depth interviews and promoted workshops with the poster producers, 'where they attempted to create a participatory methodology to investigate their experiences and collective memories'.

Closing the Special Issue, Tania Messell, through a very close reading of the International Council of Societies of Industrial Design (ICSID) archives and a detailed reconstruction of events, offers a convincing critique of globalization and design institutionalisation as colonialist projects. Her study reveals how by the 1970 s and in response to the UNIDO programme (United Nations Industrial Development Organisation), Latin America became a crucial region for ICSID. The discussion focuses on the congress held in Mexico City in 1979 to reveal how a group of Latin American designers challenged ICSID's development policies and created ALADI, the Latin American design organisation formed to promote local economic and cultural independence. ICSID, in Messell's criticism, perpetrated an 'understanding of assistance' whereby design knowledge that originated in industrialized nations was to be transferred to an expanding local Latin American industry.

What happens when research and researchers discern and foreground Latin American and Caribbean agency in design? Guided by this challenge, the above scholars yielded, interestingly, original research covering a period already crowded in the literature. Why, then, is new research still interested on the well-trodden paths of design education, the institutionalization of the profession, modern architecture and design, modernity, modernization and modernism? One possible explanation lies in the pressing need to 
intervene in current discourse with innovative methods, unprecedented sources, and critical research questions to brush history against the grain. In all contributions, the question of agency shifted according to the scale of analysis. Active dialogues, cultural creativity, and negotiations have been historicized and foregrounded without losing sight of political, economic and military dominance imposed by colonial and neo-colonial powers over the region. Routes are now open for similar inquiries to fill up gaping lacunae in current understanding.

Although still an emerging area, the number of consumption studies in the region is growing. ${ }^{75}$ The nineteenth century is a fertile historical period to explore issues of Latin American and Caribbean modernity and global exchange that escape the grip of modernist canons. ${ }^{76}$ Likewise, photography, an activity invented in isolation in Brazil, has informed scholarship preoccupied with visualization, representation and cultural autonomy. ${ }^{77}$ One cannot understand Latin America's and the Caribbean's past without questioning the enslavement of local indigenous people and the forced diaspora of enslaved African population. Their contribution to the region's design and material culture is as fundamental as unexplored. ${ }^{78}$ Popular culture and craft have been finding their way into Latin American cultural studies and design history, and a huge debt to Andean cultures is yet to be paid. ${ }^{79}$ The historiographical emphasis on modernization and nation building has largely elided enquiries into censorship, exile, democracy and citizenry in the context of twentieth-century military dictatorships. ${ }^{80}$ Similarly, few works have explored communist and socialist Latin American and the Caribbean from a design historical viewpoint. ${ }^{81}$

Guided by the decolonial principles discussed, we wish that further scholarship readdresses oppressive attitudes in design practice and discourse, and enables other worlds to co-exist in pluriversality. By foregrounding the Latin American and Caribbean experiences and proposing a re-writing of their design history we hope this might serve as a methodological orientation for further endeavours.

\footnotetext{
${ }^{1}$ Quoted in the exhibition 'Dja Guata Porã', Museum of Art of Rio (MAR), May 2017 to February 2018, curated by Sandra Benites, José Ribamar Bessa, Pablo Lafuente and Clarissa Diniz in collaboration with indigenous peoples.
} 
2 Walter Mignolo understands Western modernity as a 'fiction', a worldview and a lifeway pertained to a certain group of people however naturalized and normalized as 'reality'. Walter Mignolo, The idea of Latin America (Oxford: Blackwell, 2005).

${ }^{3}$ For Óscar Guardiola-Rivera the United States could become a Latin speaking country by 2040. See Óscar Guardiola-Rivera, What if Latin America Ruled the World? How the South will Take the North into the $22^{\text {nd }}$ Century (London: Bloomsbury Publishing, 2010).

${ }^{4}$ Mónica Gonzáles García, 'Towards a Decolonial Horizon of Pluriversality: A Dialogue with Walter Mignolo on and Around the Idea of Latin America', Lucero: Journal of the Department of Spanish and Portuguese, University of California, Berkeley, 17 (2006):38.

5 Ibid.

${ }^{6}$ Mignolo, op. cit., $x$-xiv.

${ }^{7}$ Richard Drayton and David Motadel, 'Discussion: The Futures of Global History', Journal of Global History, 13, no.1 (2018):1-21(8).

8 Other projects include Global Design History, ed. Glenn Adamson, Giorgio Riello and Sarah Teasley (London: Routledge, 2011), and D. J. Huppatz, 'Globalizing Design History and Global Design History', Journal of Design History, 28, no.2 (2015):182-202.

${ }^{9}$ Mignolo and Arturo Escobar are two of the most prominent and progressive thinkers of decoloniality in Latin America. See Arturo Escobar, Designs for the Pluriverse: Radical Interdependence, Autonomy, and the Making of Worlds (Durham: Duke University Press, 2018); Walter Mignolo, Local Histories/Global Designs: Coloniality, Subaltern Knowledges and Border Thinking (Chichester: Princeton University Press, 2000); The Darker Side of Western Modernity: Global Futures, Decolonial Options (Latin America Otherwise) (Durham: Duke University Press, 2018); and co-authored with Catherine Walsh, On Decoloniality: Concept, Analytics, Praxis (Durham: Duke University Press, 2018).

${ }^{10}$ For similar claims in Art History, see Andrea Giunta and George F. Flaherty, 'Latin American Art History: An Historiographic Turn', Art in Translation, 9, no.1 (2017): 121-142; 'Dossier: Cartographies of Design', Caiana Revista: Revista de Historia del Arte y Cultura Visual del Centro Argentino de Investigadores de Arte, ArtHist.net (Jan 13, 2018).

http://caiana.caia.org.ar/template/caiana.php?pag=articles/article 2.php\&obj=310\&vol=12, accessed 20 July 2018. In Architectural History see Felipe Hernández, Mark Millington and lain Borden, eds., Transculturation Cities, Spaces and Architecture in Latin America, Critical Studies Vol. 27 (Amsterdam and New York: Rodopi, 2005).

${ }^{11}$ Thirty-four scholars responded the original call, 8 were selected to form the panel in Aberdeen, 6 came from Latin America (Brazil, Uruguay, Colombia and Mexico).

12 https://www.designhistorysociety.org/news/view/journal-of-design-history-special-issue-locating-designexchanges-in-latin-america-and-the-caribbean, accessed 4 November 2018.

${ }^{13}$ See, for instance, the Conference 'International Design Organisations: Histories, Legacies, Values', November 2017, University of Brighton, where earlier versions of papers were presented.

14 'Special Issue: The Cold War and Latin American Studies', Latin American Perspectives, 45, no.4 (2018).

15 'Introduction', Latin American Perspectives, 4.

16 Ibid. 
${ }^{17}$ Hans-Jürgen Puhle, 'Between Academia and Politics: Latin American Studies in Germany during the Cold War', Latin American Perspectives, 45, no.4 (2018):69-97, and Ronald H. Chilcote, 'The Cold War and the Transformation of Latin American Studies in the United States', Latin American Perspectives, 45, no.4 (2018):6-41

${ }^{18}$ Victor Bulmer-Thomas, ed., Thirty Years of Latin American Studies in the United Kingdom 1965-1995 (London: Institute of Latin American Studies, 1996). See the 2014 update: 'Report on the state of UK-based research on Latin America and the Caribbean', ed. by Antoni Kapcia and Linda A Newson, Institute of Latin American Studies. For a contemporary evaluation of the Parry Report, see Harold Blakemore, 'Latin American Studies in Britain: After Parry: Report and Some Reflection', Revista de Historia de América, 65/66 (1968):129-136.

19 University Grants Committee, Report of the Committee on Latin American Studies (London: HMSO, 1965).

${ }^{20}$ Kapcia and Newson, op. cit., 8.

${ }^{21}$ Bulmer-Thomas, op. cit.

${ }^{22}$ http://news.bbc.co.uk/1/shared/spl/hi/uk/05/born abroad/countries/html/south america.stm, accessed 23 April 2018.

${ }^{23}$ US Census Bureau Public Information Office. Census.gov.

https://www.census.gov/newsroom/releases/archives/population/cb12-90.html, accessed 12 October 2018.

${ }^{24}$ Ibid., 5.

25 Gonzáles García, op. cit., 38-39.

${ }^{26}$ In 1950, the Ford Foundation set up the Foreign Area Fellowship Program (FAFP) to oversee, fund and support area-studies in the United States, contributing \$270 million to 34 universities.

${ }^{27}$ See POINTS - Potsdam International Network for TransArea Studies, by the University of Potsdam: http://www.uni-potsdam.de/tapoints, accessed 23 April 2018.

${ }^{28}$ Drayton and Motadel, op.cit, 8.

29 Ibid.

${ }^{30}$ This hindrance is shifting as local scholars start to publish original research abroad. See Ethel Leon, 'The Instituto de Arte Contemporânea: The First Brazilian Design and Art School, 1951-53', Design Issues, 27, no.2 (2011):111-124.

${ }^{31}$ Stuart Hall, Representation: Cultural Representations and Signifying Practices (London Thousand Oaks, California: Sage/Open University, 1997).

32 Escobar, op. cit.

${ }^{33}$ For a discussion on 'goodscapes' an alternative area of exchange following Appadurai's propositions, see Paula Bello, 'The Shifting Global Landscapes of Things: Goodscapes', Design and Culture, 2, no.1 (2015):63-78.

34 These include: Journal of Design History; Design Issues; Design \& Culture; West $86^{\text {th }}$; Journal of Material Culture, and Journal of Visual Culture. In Brazil, Revista Tempo, Revista Arcos and Estudos em Design have been consulted.

35 Journal of Latin American Studies (published by the Institute of Latin American Studies, School of Advanced Study, University of London); Bulletin of Latin American Research (published by the Society for Latin American Studies UK); Journal of Latin American Cultural Studies, formerly known as Travesía (1992 - 
1994); TRANSMODERNITY: Journal of Peripheral Cultural Production of the Luso-Hispanic World (University of California, United States); Latin American Perspectives (United States); Latin American Research Review (United States); European Review of Latin American and Caribbean Studies (Netherlands), and the recently issued Latin American and Latinx Visual Culture (The University of California Press).

36 Javier Gimeno-Martínez, Design and National Identity (London: Bloomsbury, 2016), 2.

${ }^{37}$ Andreas Wimmer and Nina Glick Schiller define methodological nationalism as 'the assumption that the nation/state/society is the natural social and political form of the modern world'. See 'Methodological Nationalism and Beyond: Nation-state Building, Migration and the Social Sciences', Global Networks, 2, no.4 (2002):301-34 (301).

${ }^{38}$ The Journal of Decorative and Propaganda Arts (JDPA), https://www.jstor.org/publisher/fiu Please find in the Annex complete bibliographic references to the issues and articles discussed.

${ }^{39}$ See for instance E. Basaldua's on Héctor Basaldúa and his work as stage designer at the Colon Theatre in Buenos Aires; C. Hamerman's interview of the Brazilian artist and designer Roberto Burle Marx; I. Arestizábal and E. Shaw's article on artist and designer John Graz; J.A. Gelabert-Navia's article on Cuban architecture; A.E. Mallet and D. Auerbach's piece on the mid-century furniture designer Michael Van Beuren; and L.E. Carranza's on the work of architect Mathias Goeritz.

${ }^{40}$ See J. E. Mindlin's article on illustrated books and periodicals in Brazil; M.A. Bretos' examination of Charles Edward Doty's photography in Havana at the turn of the century; M.L. Lobo Montalvo and Z. Lapique Becali's analysis of the remarkable magazine 'Social'; and R. Barajas and D.A. Auerbach's discussion of the political and aesthetic significance of Mexican caricature and its links to the Revolution. ${ }^{41}$ See for instance E. Katzenstein and E. Shaw's article on Argentine architecture; R. Sisson and E.A. Jackson's on the development of Rio de Janeiro; C. Borges Lemos and E.A. Jackson's on the modernization of Brazilian urban areas; J.A. Gelabert-Navia's on American architecture in Cuba; and J-F. Lejeune's essay on Jean Claude Nicolas Forestier's major urban works in Havana.

${ }^{42}$ See J. M. Peña's article on Art-Nouveau stained glass and ironwork.

${ }^{43}$ See M. Levisman de Clusellas and T. McNabney's article on the adoption of architectural styles in San Carlos (Bariloche) and the Llao Llao Hotel including a discussion of furniture and furnishings, designers, crafts people and local materials; Lima de Toledo's on opera houses in Brazil; G. Gomes' on the varied uses and expression of iron architecture; and F.J. Préstamo, N.G. Menocal and E. Shaw's discussion of the American sugar mills in Cuba.

${ }^{44}$ Patricia Lara-Betancourt, 'The Quest for Modernity: A Global/National Approach to a History of Design in Latin America', in Kjetil Fallan and Grace Lees-Maffei, eds., Designing Worlds: National Design Histories in an Age of Globalization (New York and Oxford: Berghahn, 2016), 241-258.

https://www.berghahnbooks.com/downloads/OpenAccess/FallanDesigning/FallanDesigning_14.pdf

${ }^{45}$ Felipe Hernández, 'Writing Identities and Constructing Heritage in Latin American Architecture', in Jonathan Harris ed., Identity Theft: The Cultural Colonization of Contemporary Art (Liverpool: Liverpool University Press, 2008), 91-107 (103). See also H. K. Bhabha, The Location of Culture (London and New York: Routledge, 1994); Lefaivre \& Tzonis, Critical Regionalism: Architecture and Identity in a Globalised World (Michigan: Prestel, 2003); F. Hernández, M. Millington \& I. Borden, eds., Transculturation Cities, op. cit. 
${ }^{46}$ Néstor García Canclini, Culturas Híbridas: Estrategias para Entrar y Salir de la Modernidad (México: Grijalbo, 1990), 65-94. English title: Hybrid Cultures: Strategies for Entering and Leaving Modernity.

47 Ibid., 75.

48 Priscila Lena Farias, 'On the Current State of Brazilian Graphic Design Historiography', Journal of Design History, 28 no.4 (2015):434-439, 435.

${ }^{49}$ Adamson, Riello and Teasley, op. cit., 3.

50 In reference to Nigel Cross, Designerly Ways of Knowing (London: Springer, 2006).

${ }^{51}$ For uses of 'origin', 'first' and 'pioneer' see: Silvia Fernández, 'The Origins of Design Education in Latin America: From the hfg in Ulm to Globalization', Design Issues, 22, no.1 (2006):3-19; Ethel Leon, 'The Instituto de Arte Contemporânea', op. cit.

52 Farias, 434-435.

53 Ibid.

${ }^{54}$ Alison J. Clarke, 'Design for Development, ICSID and UNIDO: The Anthropological Turn in 1970s Design', Journal of Design History, 29 no.1 (2015): 43-57; Marcos da Costa Braga, ABDI e APDINS-RJ: História das Associações Pioneiras de Design do Brasil (São Paulo: Blucher, 2011).

55 National Design Institute, ed., 50 Years of the National Institute of Design, 1961-2011 (Ahmedabad: NID Press, 2013). Also, Silvia Fernández, op. cit.

56 Silvia Fernández, op. cit.

57 Zoy Anastassakis, Triunfos e Impasses: Lina Bo Bardi, Aloisio Magalhães e o Design no Brasil (Rio de Janeiro: Lamparina, 2014).

${ }^{58}$ Gui Bonsiepe and John Cullars, 'Designing the Future: Perspectives on Industrial and Graphic Design in Latin America', Design Issues, 7, no.2 (1991):17-24; James Fathers, 'Peripheral Vision: An Interview with Gui Bonsiepe Charting a Lifetime of Commitment to Design Empowerment', Design Issues, 19 no.4 (2003):44-56.

59 Lucila Fernández Uriarte, 'Modernity and Postmodernity from Cuba', Journal of Design History, 18 no.3 (2005):245-255.

60 Ibid., 246

${ }^{61}$ Fathers, op. cit. In 1973, UNIDO commissioned Bonsiepe to write the report 'Development through Design'.

62 Fathers, op. cit.

${ }^{63}$ Fernández, op. cit., 246.

64 Ibid., 247.

65 Ibid., 247.

66 Ibid., 246

67 Ibid., 246-7. See also Juan Buitrago and Marcos Braga, 'Da América Latina para a América Latina: O Design como Ferramenta para o Desenvolvimento Econômico e Cultural', in Design \& Desenvolvimento: 40 Anos Depois (São Paulo: Blucher, 2015).

${ }^{68}$ Fernández, op. cit., 247.

69 Ibid., 247. 
70 Silvia Fernández and Gui Bonsiepe, eds., Historia del Diseño en América Latina y el Caribe: Industrialización y Comunicación Visual para la Autonomía (São Paulo: Blucher, 2008). Articles on modern design education include: Eduardo Castillo Espinoza, 'The School of Applied Arts, University of Chile (19281968)', Design Issues, 25 no.2 (2009):75-93; Silvia Fernández, 'The Origins of Design Education in Latin America', op. cit.; Ethel Leon, op. cit.; Verónica Devalle, 'Graphic Design as a University Discipline in Argentina, 1958-1985', Design Issues, 32 no.3 (2016):67-77.

${ }^{71}$ Farias, op. cit., 434.

72 Farias, ibid.

${ }^{73}$ Farias, op. cit., 434. These efforts resulted in the $8^{\text {th }}$ International Conference of Design History and Studies (ICDHS) in São Paulo in 2012, and the proceedings publication: Priscila Farias and Paul Atkinson, eds., Design Frontiers. Territories, Concepts, Technologies (Mexico City: Editorial Designio, 2014).

${ }^{74}$ Farias, op. cit., 434. A landmark volume that contributed to the modernist paradigm revision was Rafael Cardoso, ed., O Design Antes do Design: Aspectos da Histórica Gráfica 1870-1960 (São Paulo: Cosac Naify, 2005). For graphic design as practices of resistance and postcolonial negotiation for cultural affirmation, see Priscila Farias, 'On graphic memory as a strategy for design history', Proceedings of the $9^{\text {th }}$ Conference of the International Committee for Design History and Design Studies (São Paulo: Blucher, 2014), 201-206. Robin Adèle Greeley convincingly argues that graphic design can disrupt hegemonic cultural narratives in 'Richard Duardo's 'Aztlán' Poster: Interrogating Cultural Hegemony in Graphic Design', Design Issues, 14 no.1 (1998):21-34.

75 See Frank Trentmann and Ana María Otero-Cleves, "Presentation. Paths, Detours, and Connections: Consumption and Its Contribution to Latin American History," Historia Crítica 65 (July-Sep 2017):13-28, doi:dx.doi.org/10.7440/histcrit65.2017.01. New research includes, among others: Ana María Otero-Cleves, 'Foreign Machetes and Cheap Cotton Cloth: Popular Consumers and Imported Commodities in NineteenthCentury Colombia', Hispanic American Historical Review 97, no.3 (2017):423-256; and Ana María Fernández-García, "Little flat furnished by Maple..." The "English Taste" in Buenos Aires: The Thompson and Maple Companies (1887-1986)', Journal of Design History, 29 no.2 (2016):137-160. Pioneering work in this area include Benjamin Orlove, ed., The Allure of the Foreign: Imported Goods in Postcolonial Latin America (Michigan: University of Michigan Press, 1997) and Arnold J. Bauer, Goods, Power, History: Latin America's Material Culture (Cambridge: Cambridge University Press, 2001); see also Patricia LaraBetancourt, 'La Sala Domestica en Santafé de Bogotá, Siglo XIX. El Decorado de la Sala Romántica: Gusto Europeo y Esnobismo', Anuario Colombiano de Historia Social y de la Cultura 25 (1998):109-134.

${ }^{76}$ Livia Rezende, 'Manufacturing the Raw in Design Pageantries: the Commodification and Gendering of Brazilian Tropical Nature at the 1867 Exposition Universelle', Journal of Design History, 30, no.2 (2017):122138; Livia Rezende, 'Of Coffee, Nature and Exclusion: Designing Brazilian National Identity at International Exhibitions, 1867 \& 1904', in Lees-Maffei and Fallan, eds., op. cit., 259-273; and Livia Rezende, 'The Artifice of Nature and the Naturalisation of the State at the Rio de Janeiro International Exhibition', in Marta Filipova, ed., Cultures of Exhibitions (London: Ashgate, 2015), 163-182.

77 Among others, Boris Kossoy, Hercule Florence: A Descoberta Isolada da Fotografia no Brasil (São Paulo: Editora Edusp, 2006); Louise Purbrick, 'Nitrate Ruins: The Photography of Mining in the Atacama Desert, Chile', Journal of Latin American Cultural Studies, 26 no.2 (2017):253-278; Brendan Lanctot, 'The Tiger and the Daguerreotype: Early Photography and Sovereignty in Post-Revolutionary Latin America', Journal of Latin American Cultural Studies, 24 no.1 (2015):1-17; Elizabeth Edwards \& James Scorer, 'Visualising Traces of the Past in Latin America', Journal of Latin American Cultural Studies, 26 no.2 (2017):131-139. 
${ }^{78}$ Key new work include Agnes Lugo-Ortiz, 'Material Culture, Slavery, and Governability in Colonial Cuba: The Humorous Lessons of the Cigarette Marquillas', Journal of Latin American Cultural Studies, 21 no.1 (2012):61-85; Anna Cant, "'Land for Those Who Work It": A Visual Analysis of Agrarian Reform Posters in Velasco's Peru', Journal of Latin American Studies, 44 no.1 (2012):1-37

79 See E. Martens, 'Caribbean Popular Culture: Everyday Lives, Racial Politics and Transnational Movements', European Review of Latin American and Caribbean Studies, 102 (2016):101-108; Lina Bo Bardi, 'Three Essays on Design and the Folk Arts of Brazil', West 86 ${ }^{\text {th }}$ : A Journal of Decorative Arts, Design History \& Material Culture, 20 no.1 (2013):110-124; Luciana Martins, Sven Helmer and Denise Y. Arnold, 'Exploring Weaving Structures in the Andes: Reflections on the Creation of a Digital Archive', Visual Resources, 29 no.1-2 (2013):59-71.

${ }^{80}$ Randal Sheppard, 'Clara Porset in Mid Twentieth-Century Mexico: The Politics of Designing, Producing, and Consuming Revolutionary Nationalist Modernity', The Americas, 75 no.2 (2018):349-379; Emilse B. Hidalgo, 'Argentina's Former Secret Detention Centres: Between Demolition, Modification and Preservation', Journal of Material Culture, 17 no.2 (2012):191-206, among others.

81 Jessica Gordon-Burroughs, 'Straight Pins, Gauze, and Linotypes: The Cuban Post-Soviet Artists', Journal of Latin American Cultural Studies, 26 no.3 (2017):437-459; Eden Medina, 'Designing Freedom, Regulating a Nation: Socialist Cybernetics in Allende's Chile', Journal of Latin American Studies, 38 no.3 (2006):571606; Giuliana Bruno, 'Havana: Memoirs of Material Culture', Journal of Visual Culture, 2 no.3 (2003):303324. 